\title{
Nuances of the Odebrecht Case Coverage by American, Brazilian, Latin American and European Media: Criminalization of Corruption or Ideology?
}

\author{
Dr. Alvaro Nunes LARANGEIRA \\ Universidade Tuiuti do Paraná (UTP) \\ Rua Sydnei Antonio Rangel Santos, 238 \\ 82010-330 - Curitiba - PR - Brasil \\ alvarolarangeira@gmail.com \\ Dr. Franco IACOMINI JR. \\ Universidade Estadual do Centro-Oeste (Unicentro) \\ Rua Padre Salvatore Renna, 875 \\ 85015-430 - Guarapuava - PR - Brasil \\ fiacomini@gmail.com \\ Dr. Tarcis PRADO JR. \\ Universidade Tuiuti do Paraná (UTP) \\ Rua Sydnei Antonio Rangel Santos, 238 \\ 82010-330 - Curitiba - PR - Brasil \\ tarcisjr@yahoo.com.br \\ Dr. Moisés CARDOSO \\ Universidade Regional de Blumenau (FURB) \\ Rua Antônio da Veiga, 140 \\ 89030-903 - Blumenau - SC - Brasil \\ beiocardoso@gmail.com \\ Msc. Antonio Carlos Persegani FLORENZANO \\ Universidade Tuiuti do Paraná (UTP) \\ Rua Sydnei Antonio Rangel Santos, 238 \\ 82010-330 - Curitiba - PR - Brasil \\ abonico@gmail.com
}

\begin{abstract}
:
Brazilian construction company Odebrecht is present in 25 countries, such as the United States, Mexico, Panama, Cuba, Venezuela, Ecuador, Colombia, Argentina, Angola, Mozambique, Portugal and Germany. The United States Department of State considers the case of the Brazilian company as the "greatest case of global corruption in history", due to the payment of US \$1 billion in bribes to political parties and governments in 12 countries, and the episode played a decisive role. in the Brazilian impeachment of ex-president Dilma Rousseff. The media approach of Odebrecht case's has presented analytical nuances related to the mentioned countries. Reports on socialist Cuba, Bolivarian Venezuela and progressive Ecuador associate Odebrecht's shadowy procedures with the central core of the respective governments, while in the case of right-wing and center-right governments corruption reaches only the lower echelons, disregarding the central power. And in the American case, there is the unique cover-up of the executive power accountability in the corrupting process. The present review proposes, from the Critical Discourse Analysis, by Teun A. van Dijk, and from the concepts of Discursive Formations and Operative Neutrality, by Michel Pêcheux, to understand the investigative dissonances on the part of the media, based on the proposition that the corruption's phenomenon has its own understanding and criminalization for the media field. Those concepts are conditioned to cultural, geopolitical and ideological instances, with which media firms are identified or with which they repudiate.
\end{abstract}

Keywords: Critical Discourse Analysis, Discursive formations, Operational neutrality, Media, Corruption, Odebrecht case's 


\section{Introduction}

Operation Lava Jato ("car wash") was started in March 2014 seeking to identify a money laundering structure that operated in Brazil with expressive values. Initially, investigations by federal prosecutors in Curitiba focused on four criminal groups led by currency market vendors, known as 'doleiros'.

As the investigations developed, federal prosecutors found a corruption scheme involving Petrobras (Ministério Público Federal, s / d), Brazilian partially state-owned oil company. It was the beginning of the biggest action against corruption of all Brazilian history, compared by media to Operation Mani Pulite, which investigated mafia, businessmen and politicians in Italy in the 1990s.

Lava Jato investigations were largely based on revelations obtained through plea bargains, from collaborative defendants. From the emphasis given to them, it is possible to identify different strategies used by media at the time the facts were disclosed. This mechanics influences the perception of facts when they are interpreted by society. This occurs because journalism, for the most part (news, reporting and interview), follow an advisory script that depends on third parties to verify the information. Informers appear, determined to modify the setting that surrounds them, having particular intentions, already pointed out by Flynn (2011) in his theories.

Brazilian prosecutor's revelations have found a favorable climate for their disclosure, even in the international news outlets. In the previous year, Edward Snowden denounced U.S. National Security Agency (NSA) acts (Greenwald, 2014); Chelsea Manning was singled out as the source of document leaks for the WikiLeaks website, headed by Julian Assange, in operation since 2006. There was then a media predisposition to follow major alliances between criminal groups and politicians, with its intricate network of collaborations. The Panama Papers are also one of the great historical leaks of journalism (Baack, 2016), also accompanied by the unveiling of money laundering networks and the cover-up of powerful people.

Except for the data sharing carried out by Edward Snowden on the NSA, the other leaks from 2009 presented similarities, which may suggest a new methodology in journalism, putting in discussion several aspects of professional ethics. Such collaborative techniques are embraced as a way of preserving the figure of the gatekeeper, serving as "ideological commitment to journalism with control, [...] giving rise to a hybrid logic of adaptability and openness [...], thus finding a normative purpose in transparency and participation" (Lewis, 2012: 851).

We've also observed journalistic projects motivated by bringing up restricted circulation documents, such as the example of "100Reporters" and the "FolhaLeaks", the latter considered as the beginning of the Brazilian press response to the information leakage panorama (Flor, 2014). Within this line of events, the complaints involving Brazilian multinational company Odebrecht have triggered a series of actions that further investigation by Communication Sciences, to reveal and ponder about the format and language printed newspapers in Brazil and other countries.

To elaborate this article, texts obtained from the following communication vehicles were used: Colombian El Tiempo (www.eltiempo.com), Ecuadorian El Universo (www.eluniverso.com), USA's Miami Herald (www.miamiherald.com) and portuguese Diário de Notícias (www.dn.pt), such as their respective search engines. The information screening has been done using the expression "Odebrecht" or, also, using tags informed on the website's homepage. The cutoff date, from which the reports were no longer considered, is April 1, 2018.

There was no restriction of a search period, and articles have been analyzed starting in 2012 - before the outbreak of the bribe scandal revealed by Operation Lava Jato. Thus, regarding this article's nature, it is classified as basic, exploratory and bibliographic research. Exploratory research develops, elucidates, and transforms concepts to obtain a broad view of a given event (Malhotra, 2012). It provides criteria about the problem and its understanding. Bibliographical research provides a theoretical basis for arriving at new scientific developments (Lakatos and Marconi, 2001). And finally, it fits in as a qualitative research that seeks to "examine and reflect perceptions to obtain an understanding of social and human activities" (Collis and Hussey, 2005: 26). It is important to emphasize that the type of sample selected is the intentional non-probabilistic, which is the one in which the data selection to compose the sample depends, in part, on the researcher's judgment in data collection (Mattar et al., 1996).

Carrying out researches on the scientific basis of the Brazilian Coordination for the Improvement of Higher Education Personnel (Capes) website, a federal agency responsible for the follow-up of the stricto sensu Brazilian PostGraduation, by the term "Odebrecht", 1,236 peer-reviewed articles were identified. Works of Boswell (2013);

1Available in <https://100r.org/wa/> (accessed on 11 August 2018).

2Available in <http://folhaleaks.folha.com.br〉 (accessed on 11 August 2018). 
Brito and Oliva (2009); Lamb, Lacerda and Dresch (2017); Machado (2008); Spitzeck, Boechat and France Lion (2013) stand out, among others. Then, the terms "Odebrecht" and "corruption" were added, and 53 peer-reviewed articles were identified, highlighting the work of Bragio Bonaldo (2017); Brasão and Júnior (2016); Gonçalves (2017); Kurtenbach and Nolte (2017); Matovska, Trajkoska and Siljanovska (2014). As it can be seen, the study of the corruption scheme installed by Odebrecht in different countries has drawn the attention of different researchers.

What is proposed in this research is a new cut of this communication and political unfolding that can collaborate for the academic community, thus proving its scientific relevance. This work is divided into the following sections: Introduction, Methodological Resources, Odebrecht in the News and Conclusion.

\section{Methodological resources}

In this section we present the methodological resources that guide our study, namely, the Critical Discourse Analysis in Van Dijk and, in particular, the emphasis on discursive formation and operative neutrality with Pêcheux. We believe that these theorists can help us clarify, unveil and bring out the essence of what was addressed in the Odebrecht materials in the media of those countries that form part of this work's corpus. We begin the section presenting the Critical Discourse Analysis, then we proceed to develop the notion of discursive formation, highlighting how the ideology is quite present in the enunciating subject's articulation, and then we end up evidencing the operative neutrality as a contribution to the unveiling of what has been identified in the speeches about the Brazilian company's case abroad.

\subsection{Critical Discourse Analysis}

Discourse Analysis itself is not a method, but a domain of academic practices, distributed throughout all human and social sciences (Van Dijk, 2008: 11). Thus, there is no "analysis" of discourse as a method, nor is there "a" social analysis or "cognitive analysis." Both Discourse Analysis and Critical Discourse Analysis consider the study of writing and speech structures in the areas of grammatical analysis (phonological, syntactic, lexical, semantic); the pragmatic analysis of speech acts and communicative acts; of rhetorical analysis; of stylistic analysis; analysis of specific structures (gender, narrative, argumentation, news stories, textbooks, etc.); conversational analysis of speech in interactions; of the semiotic analysis (sounds, images), and other multimodal properties of discourse and interaction (Van Dijk, 2008: 12).

The discourse is not only verbally analyzed, but involves the context in which it operates, in the situated interaction, a social practice (Van Dijk, 2008). So, instead of analyzing just the interaction between co-workers, for example, one must search mainly for the whole context in which those people work, with particularities that can affect - or not - the statement, and the temporal and spatial situation in which the discourse is being developed. The Critical Discourse Analysis will focus on highlighting the power (and its relations) underlying speech or writing and "its methods are chosen so that research can contribute to the social empowerment of dominated groups, especially in the field of discourse and communication" (Van Dijk, 2008: 13).

This domain operates by power, which Van Dijk (2008) denominates control, "that is, control of a group over other groups and their members" and their actions, in terms of control, that translate into control over the discourse of others, as explained below:

people are not free to speak or write when, where for whom, about what or how they want but are partially or totally controlled by powerful others such as the state, police, media or a company interested in suppressing freedom of writing and speaking (typically critical). Or, on the contrary, they have to speak or write as they are told to speak or write (p. 18).

Power is disclosed on two levels: macro and micro. The practice of language, discourse, verbal interaction and communication belong to the micro level of social order. Domination, power, and inequality among social groups are typically terms belonging to a macro analysis.

For example, a racist pronouncement in the National Congress is a discourse at a micro-level of social interaction, in the specific situation of a debate, but at the same time it may represent or be a constituent part of a legislation or the reproduction of racism in the macro level (Pêcheux, 2011: 116).

Thus, there are some ways of analyzing these levels, such as focus on group members, thinking about the interaction of organizations, groups and their members; the actions-processes, involving the news production; personal and social cognition, highlighting memories, knowledge and personal opinions and one in particular, related more specifically to our object of study, that is the context-social structure, or what is part or constituent of the social structure, such as a press conference (typical practice of media organizations), that is, "it is the 'local' and 'global' contexts which are closely related, both imposing restrictions on discourses" (Pêcheux, 2011: 117) . 
These impositions are an expression of power and Pêcheux (2011), as well as Van Dijk (2008), also defines it as control, stating that certain groups have greater or lesser power according to the control (greater or lesser) that they can exert over others. This is only possible if there is a power base that allows privileged access to scarce resources such as strength, money, status, fame, knowledge and information.

Thus, in relation to the types of power we have that the military is based on the force, that of the rich, on the money and that of the journalists, on the information, knowledge and authority that comes from them, materialized in the media discourse through devices such as newspapers, radios, TVs and, presently, internet portals. Thus, "it is also vital for every discourse and all communication who controls the themes (semantic macro-structures) and the change of topic, just as it happens when editors decide what news topics will be covered" (Gans, 1979; Van Dijk, 1987c, 1988b apud Pêcheux, 2011: 120).

Thus, to understand how power influences the discourse, Van Dijk has proposed another modality of analysis: the Critical Discourse Analysis. This mode of analysis is "a type of discursive analytical research that mainly studies how abuse of power, domination and inequality are represented, reproduced and counteracted by oral and written texts in the social and political context" (2008: 113). In this way, researchers who adhere to this type of analysis seek, in addition to understanding and unveil the discourse and its particularities, ultimately, to oppose social inequality.

For critical discourse analysts, a critical awareness of their role in society is fundamental [...] because they argue that science and in particular academic discourse are not only an inherent part of a social structure, but are also influenced by it, as well as being produced in social interaction (Van Dijk, 2008: 114).

That means, it is a type of analysis that puts words, expressions and phrases in a sociopolitical perspective, where they always exist related to others, inserted in predetermined contexts.

\subsection{The discursive formation}

The meaning of a word, an expression, a proposition, etc., does not exist "in itself" - that is, in its transparent relation to the literality of the signifier - but, on the contrary, it is determined by the ideological positions which are at stake in the socio-historical process in which words, expressions and propositions are produced (reproduced). That means: words, expressions and propositions, etc., change their meaning according to the positions held by those who use them. Pêcheux (1995: 160) denominates discursive formation in this way:

What, in a given ideological formation, that is, from a given position in a given conjuncture, determined by the condition of class struggle, determines what can and must be said (articulated under the form of a harangue, a sermon, of a pamphlet, and an exhibition, of a program, etc.)

That is, words, expressions, propositions, and so on acquire their discursive formation sense, in which they are produced through the materialization of discourse and meaning, which, in this case, individuals are "interpellated" in subject-speakers (subjects of their discourse) by the discursive formations that represent "in language" their correspondent ideological formations.

In this sense, if the same word (expression and proposition) can receive different meanings as it refers to this or that discursive formation, it is because this group does not have a meaning that would be "own", linked to its literality. On the contrary, its meaning is constituted in each discursive formation, depending on the relations that these (words, expressions or propositions) maintain with other words, expressions or propositions of the same discursive formation (Pêcheux, 1995). And also in admitting that the same words change their meaning in the passage from one discursive formation to another, it is also necessary to admit that literally different words (and expressions and propositions) can, within a discursive formation, "have the same meaning", which in fact represents the condition for each element to be endowed with meaning. Thus, "the discursive process expression will come to designate the system of substitution relations, paraphrases, synonyms, etc., that work between linguistic elements - 'signifiers' - in a given discursive formation" (Pêcheux, 1995: 161).

In this way, discursive formation is its matrix (place of its constitution of meaning) and this is evidenced in the following thesis (Pêcheux, 1995: 162): "All discursive formation conceals, by the transparency of the sense constituted in it, its dependence on the 'all dominant complex' of discursive formations." Pêcheux (1995) denominates interdiscourse the "all dominant complex" of discursive formations and under these conditions that is proper to all discursive formation to disguise, in the transparency of meaning, the contradictory material objectivity of this interdiscourse, which determines this discursive formation as such. It is the objectivity that materializes itself in "something speaks" always "before, in another place and independently", in other words, under the complex of ideological formations' domain. 
Thus, ideology works as an interpellation of individuals into subjects (of their discourse) and this is done through the complex of ideological formations providing "to each subject" "his reality" within a system of accepted and experienced evidences and significations (Pêcheux, 1995). By analyzing the discursive properties of the subject-form, we should not forget the "ego-imaginary" as the subject of discourse, that is, where its imaginary relation to reality (where its subjugation to the Other happens ${ }^{3}$ ).

Thus, this ego-imaginary is the subject of discourse and this is constituted by the "forgetting" ${ }^{4}$ of what determines it and then this interpellation of the subject as subject of his discourse is effected by the identification of the subject with the discursive formation that dominates him, or in which it is constituted as subject. Therefore, this identification is because the elements of interdiscourse are like a pre-constructed and sustaining process ${ }^{5}$, constituted in the subject's discourse. The characteristics of what determines it are reinscribed in the subject's discourse itself.

The subject-form (which is where the "subject of discourse" identifies itself with the discursive formation that constitutes it) tends to absorb-forget the interdiscourse in the intradiscourse, that is, it simulates the interdiscourse in the intradiscourse, so that the interdiscourse becomes evidence of the intradiscourse's "already said" pure, in which it is articulated by "co-reference", that is, the joint effect by which the stable identity of the "referents" (of what is in question) is guaranteed on the thread of speech (Pêcheux, 1995: 167).

In this way, the discourses reveal (and unveil) the enunciating subject and cannot be separated from it. That is, there is no subject-discourse separation since in vocalizing, when enunciating something, the subject already reveals in this process, his ideology. Discourse is then chiseled by ideology without being dissociated. Regardless of science, philosophy or other areas, languages exist and linguistics circumscribes it restricted to a materiality without often realizing that it can surpass its limits of impact, revealing also that there is always "something behind" (Pêcheux, 1995), as Lenin once said: "the tongue always goes where the tooth hurts" (Pêcheux, 1995: 87). In this way, linguistic mechanisms form the background of a philosophical reflection, that is, the technical questions of a language structure and its phenomena cannot be "read" only from the language functioning perspective in relation to itself, but much moreover: from what is drawn from it.

The linguistic system is the same for different shades: idealists, materialists, revolutionaries, reactionary, for those who have knowledge and who do not. However, it is impossible to assert that everyone has the same discourse even because language is, so, presented as the common basis of discursive processes and thus: "It is, therefore, on these internal law's basis that the discursive processes are developed, and not as an expression of pure thought, pure cognitive activity, etc., which would 'accidentally' use linguistic boundaries (Pêcheux, 1995: 91)".

It is not possible, then, to superimpose the discourse/language opposition to concrete/abstract, because discursiveness is not the speech (parole). In other words, the individual "concrete" way of containing the language's "abstraction"; it is not simply the use of a function, but rather to put the notion of speech (parole) in its place (idealist), together with the psychologistic anthropologism that it conveys.

If what is said, enunciated by means of (and by) ideology contains semantic elements that can induce transformations or inflate certain actions, the same can be said of emitters whose syntax and semantics are assumed to be absolutely neutral. There is no neutrality, since any "pseudoneutrality" means something (or rather, being at the service of) and this is what we will talk about next.

\subsection{Operative neutrality}

Studying the propaganda, Pêcheux considers to happen an ideological war, characterized by diverse mass operations by the bourgeoisie against everything that resists to it. "The underlying idea is that we must respond for an even more effective counter-propaganda: to war, as in war ..." (Pêcheux, 2011: 73), as in Armistice France during the Nazi occupation in which the French State employs all means to convince the people that the Marshal acted for their own good, freeing them all from the worldwide Jewish-Bolshevik danger. In this way, advertising becomes a state matter that will use a biopsychological scheme that Pêcheux (2011) summarizes in three theses: i) human nature is constituted by impulses:

3 This subordination-subjugation takes place precisely in the subject, under the form of autonomy, in an allusion to Lacan: "The subject is subject only by its subjugation to the field of the Other" (Lacan, 1979: 178)

4 It is not the loss of something, but the cover-up of the subject's cause in the very interior of its effect (Pêcheux, 1995: 183).

5 The pre-constructed is the "always-already-there" of ideological interpellation, which provides-imposes "reality" and its "meaning" under the form of universality (world of things), while the process of support (articulation) is the subject in its relation to meaning (Pêcheux, 1995: 164). 
food and economic, in which propaganda operates by the argumentative bias, based on education through observation and reflection; and by the affective impulse, which is aggressive, combative, leading to a military propaganda of reflexes and emotions, supported by an aesthetic-religious liturgy of signs and gestures; ii) the objective process of these impulses materializes (being controlled, instrumentalized and placed at the service of any policy) in the network of journalistic metaphors (barrage, hammering with grenades, heavy artillery, conspiracy, infighting, etc. .,) that each one uses without realizing it. It is in this second thesis which, in order to evidence this forces' relation in a discourse, and to show that seemingly harmless, neutral terms, without any damage potentials, can work in their pseudoneutrality as devices for reinforcing concepts and ideas (of dominant groups in relation to their "opponents"), the author forges "the idea of operative neutrality of instruments symmetrically engaged in confrontation between the fields" (Pêcheux, 2011: 78).

The third thesis is that the metaphorical war engages the fate of thousands of people who, according to the strategy of a "propaganda campaign", will follow this or that direction, "hence the responsibility of those who, holding the weapons of propaganda, set goals and regulate the shot: the responsibility of those whom we rightly call 'the directions' [...] to the face of 'the mass' of all who are this propaganda struggle's object" (Pêcheux, 2011: 79).

The analysis of this study's material, therefore, aims to show how discourses with apparently "unpunished" terms or words can, through operative neutrality, reveal - and unveil - the true sense of the speaker-subject of discourse (and its context), bringing with it the ideology and the traits of power that emerge from the atmosphere of those who emit them. This is what we discuss in more detail, in the next section.

\section{Odebrecht on the news}

For the purposes of this work, the publications about Odebrecht in selected media from Ecuador, Colombia, Peru, the United States and Portugal were analyzed. The analysis have been done using search engines resident in each website, preferably searching for aggregators already present in the pages, such as specific editorials or tabs identifying relevant news topics.

\subsection{Ecuador}

In Ecuador, the analyzed media vehicle was the daily "El Universo", in Guayaquil, country's most populous city and an important economic center. Founded in 1921, "El Universo" was in 2014 the 11th printed newspaper with the greatest influence on social networks, according to a survey published by the Huffington Post news website (Riveros, 2014). The newspaper has on its website a tag (a digital thematic marker) identifying the contents linked to the Odebrecht case and its repercussions in the country. Through this route it is possible to find reports about the Odebrecht case in Ecuador itself and also in other countries, notably Brazil, Colombia, Peru and Bolivia.

According to a summary prepared by the newspaper's team (El Universo, 2017), the Odebrecht scandal hit the country in December 2016, when the United States Department of Justice announced that it had entered into an agreement with Odebrecht and Braskem (belonging to the same business group), by which Brazilian companies admitted guilt by paying bribes to authorities of twelve countries, namely Angola, Argentina, Brazil, Colombia, Ecuador, Guatemala, Mexico, Mozambique, Panama, Peru, Dominican Republic and Venezuela (Department of Justice, 2016a). By that agreement, the two companies agreed to pay $\$ 3.5$ billion in penalties "to settle the largest case of international bribery in history" (ibid., 2016b). The lawsuits have been filed in New York and are backed by the Foreign Corrupt Practices Act. According to information from the US case, Odebrecht would have paid approximately $\$ 788$ million in tips to government and partisan authorities in several countries, with the goal of gaining business advantage in those nations (Department of Justice, 2016b).

The newspaper El Universo reports that Carlos Pólit (formerly responsible for the country's Comptroller's Office) and the then Vice President Jorge Glas were appointed by the investigators as Odebrecht contacts in Ecuador. Both of them, together with Odebrecht executive José Conceição dos Santos (Brazilian citizen), would be the head of the corruption scheme set up by the company in this country (El Universo, 2017a). According to the daily, Odebrecht admits to having paid bribes related to the works of the Manduriacu hydroelectric project, from the land movement to the Refinery of the Pacific, the irrigation project Daule Vinces, Poliduto Pascuales Cuenca and the La Esperanza aqueduct (El Universo, 2017a). The stories, in general, are published in the Politics section of the Ecuadorian daily. Jorge Glas has been arrested on October 2, 2017 and sentenced the following December to six years in prison. As a result, Ricardo Rivera Aráuz, uncle of Glas, was sentenced in the same act. The former vice president denies the accusations and presents himself as a political persecuted (El Universo, 2017b).

In March 2018 the newspaper published a text from the Associated Press news agency under the title "Odebrecht pide disculpas a Ecuador por escándalo de millonarios sobornos" (El Universo, 2018), reporting a formal apology made by Odebrecht Ecuadorian subsidiary, posted on its website. 
In it, the company states that it has removed all those accused of illicit from its operations in the country and "appreciates the opportunity to collaborate with the judicial authorities in the fight against corruption" (Odebrecht Ecuador, [S.d.]).

The relationship between the newspaper "El Universo" and the Ecuadorian government is not the most favorable. In 2012, the Ecuadorian courts sentenced the newspaper to pay a \$ 40 million compensation to then-President Rafael Correa in a case in which Correa alleged injury (Mena Erazo, 2012). Days after the sentence's ratification, Correa announced pardon to those involved (El Universo, 2012).

Jorge Glas, now accused of corruption, served as Correa's vice president between 2013 and 2017. From May 2017 until his retirement in December 2017, he was vice president of Lenin Moreno, the current head of the Ecuadorian Executive.

\subsection{Colombia}

The Colombian newspaper being used as research source in this work is "El Tiempo", in Bogotá, classified as the most influential printed newspaper in Latin America, according to the already quoted Huffington Post ranking (Riveros, 2014). Contrary to what happens with the Ecuadorian "El Universo", the Colombian daily does not have a specific tag for the case nor a text that summarizes what has been investigated in the country. The themes are dealt with in individual reports.

Report published on July 26, 2017 indicated the involvement of three parliamentarians in the case of corruption (El Tiempo, 2017c). Four months later, the Prosecutor's Office opened an investigation against eight parliamentarians (El Tiempo, 2017d). Few members of the Colombian Executive are mentioned in the reports. One of them is Gabriel García Morales, former deputy minister of Transportation during Alvaro Uribe's government (who presided over the country between 2002 and 2010). The then president, Juan Manuel Santos, is accused of receiving illegal Odebrecht donations, which would have fueled his presidential campaigns in 2010 (El Tiempo, 2017a) and 2014 (El Tiempo, 2017b). Santos left office in August 2018, being succeeded by Iván Duque Márquez.

According to United States Department of Justice documents (Department of Justice, 2016a: 18), Odebrecht paid \$ 11 million in kickbacks in Colombia to obtain contracts with the government between 2009 and 2014 (during the mandates of Andrés Pastrana, Alvaro Uribe and Santos, the latter took office for his first term on August 7, 2010, and was reappointed to the post four years later). The Santos family has a long-standing relationship with the newspaper El Tiempo. His great-uncle Eduardo Santos Montejo, who presided over the country between 1938 and 1942, acquired the newspaper. The father of Juan Manuel Santos, Enrique, was one of its editor-chiefs. The president himself even had a leading position in the newspaper.

When the advanced search of the website of "El Tiempo" is changed to present the results by relevance, it brings as a first result a cartoon. Dated from July 14, 2017 and written by the cartoonist Jota, the picture presents three cages, each one identified by signs placed at its base: Brazil, Peru and Colombia. In the left cage is former Brazilian President Luiz Inácio "Lula" da Silva. In the middle, the former president Alejandro Toledo. On the right, a traditional image of Justice, carrying a scales and blindfolded. The title of the cartoon is "Results against Odebrecht" (Jota, 2017), denoting that, in each country, the investigations resulted in the identification of responsibilities for the events that occurred in the country. In Brazil, responsibility - in the view expressed by Jota's cartoon - would have been attributed to Lula (who at the time had been indicted and charged by the Public Prosecution Service, but had not received any conviction in Odebrecht cases). In Peru, the criminal relationship with Odebrecht would have been, primarily, Toledo. In the Colombian case, there are two possibilities for understanding the image (and both exempt the national executive, which at the time was directed by Juan Manuel Santos, whose family commands "El Tiempo"): for the first, omission and fails to impute guilt, and therefore may itself be guilty; for the second, justice is guilty of throwing false accusations about the authorities. In an editorial, "El Tiempo" points out that President Santos (reiterating: whose family has been a member of the newspaper for more than 70 years) had ordered a determination on the theme, "whoever falls". The newspaper's opinion puts Santos as the decision maker who will be able to exorcise corruption in the country (El Tiempo, 2017e) - a task that does not match with someone accused of receiving improper resources, which leads to the conclusion that the newspaper prefers to criminalize justice, imputing inaction to it.

\subsection{Peru}

Founded in 1839 in Lima (Peru's capital) and the country's leading newspaper, the daily "El Comercio" has developed a neutral stance on news regarding the issues on accusations and suspicions of political corruption and money laundering in the country. Between the first day of March 2017 and the first day of April 2018, we've researched using El Comercio's website search engine, and there were found 1,491 news items with the words "Odebrecht" and "Kuczynski". 
Being a liberal trend and linked to center-right politics, the economist Pedro Pablo Kuczynski, also known by the initials of their names (PPK), held the position of prime minister between 2005 and 2006, during the government of Alejandro Toledo. In a disputed presidential election in 2016, he overcame his rival and opponent Keiko Fujimori in the second round, by a margin of only $0.25 \%$ of total votes.

In March 2017, when the wave of Odebrecht-related scandals began to spread across Latin America, a poll found that $60 \%$ of the Peruvian population believed that PPK was not only not fighting corruption but also protecting the former president Alejandro Toledo. In addition, 66\% believed that Kuczynski had received bribes from Odebrecht when he held the position of minister during the administration of Toledo (El Comercio, 2017a).

In July, after 180 days of investigations by the Public Prosecutor's Office, including in president's accounts, two former presidents, Ollanta Humala and Alan García, and the then representative, Kuczysnki, were summoned in the Peruvian Lava-Jato process. PPK has been accused of receiving illegal payments through his company Westfield Capital, managed by Chilean partner Gerardo Sepúlveda, using overpriced construction works (El Comercio, 2017b).

Gradually, Kuczynski government ministers left the government, also accused of corruption. In September 2017, Prime Minister ${ }^{6}$ Fernando Zavala received the parliamentary vote of no confidence and resigned (El Comercio, 2017c). As the end of the year approaches, Pedro Pablo and Keiko Fujimori, leader of the Fuerza Popular party, met frequently to discuss the support of the presidential bloc to ensure Kucyznski to remain in power. Among the exchange coins was the controversial Christmas pardon to Keiko's father, former President Alberto Fujimori, imprisoned for seven and a half years for corruption. One of the promises of the PPK campaign was precisely its opposition to any possibility of releasing the condemned politician (El Comercio, 2017d). In March 2018, an anti-corruption task force held a search and seizure service in three properties registered on behalf of Kuczynski for more than twelve hours (El Comercio, 2017e). Judge Juan Carlos Sanchéz also prevented him from leaving the country for a period of 18 months (El Comercio, 2017f).

After constant stress with the opposition, controversial attitudes, declarations of innocence and victimization of its economic policy, popular pressure and successive losses before the country's Justice, Pedro Pablo Kuczynski resigned his position on March 21, 2018, after being in charge of presidency for 21 months. This happened after the announcement of three audios of a conversation between the Minister of Transports and Communications, Bruno Giuffra, and the "fujimorian" parliamentary Moisés Manami, regarding the negotiations of votes exchanging aiming at the president's permanence. Two days later, Martin Vizcarra took over the presidency. PPK came to occupy the leadership of his party, Peruanos por el Kambio.

The daily "El Comercio" is part of a business group of the same name, which accounts for a considerable media market share in its country. It owns nine national newspapers and 13 other digital media. After consolidating the purchase of $100 \%$ of the Epensa group, completed in April 2018, it now controls 82\% of the circulation of all printed newspapers in the country. The group also includes the newspapers "Trome", "Ojo", "Depor", "Correo", "Perú21" and "Publimetro", all among the ten most read in Peru. Estimates for 2016 indicate that the El Comercio group absorbed about $60 \%$ of the net revenue of the nine major media groups in the country. The high concentration caused a group of journalists, including the editor of the newspaper "La Republica", Augusto Álvarez Rodrich, to appeal to the courts alleging that there were risks to freedom of press. By 2015, the group's audience totaled 62.5 million unique users, making it the national leader in digital media. Its audience is almost five times that of the second-place group - the RPP group, which registered 11.5 million unique users. The El Comercio group is also a shareholder in country's main television network, América Televisión. Its partner in this business is Grupo La República (Reporteros Sin Fronteras, [s.d.]).

"El Comercio" is run in 2018 by the same family that founded it, Miró Quesada. This does not mean that he has always been owned by the same group. Like all the country's media, between 1974 and 1980 "El Comercio" was nationalized by the left-wing military dictatorship that ruled Peru. The Reporters Without Borders organization says the newspaper's shareholders and executives are more attuned to the business world than to the political one. Even so, Reporters Without Borders reports that several analysts point out that "El Comercio" would have supported Alan Garcia and Keiko Fujimori, right-wing candidates, in the 2006 and 2011 (Reporteros Sin Fronteras, [s.d.]) elections. In 2011, the Spanish newspaper "El País" canceled, at the request of the Peruvian writer Mario Vargas Llosa, the sending of the Llosa column to "El Comercio".

6 In the presidential political system adopted in Peru, the prime minister (or president of the Council of Ministers) is a more qualified advisor to the president of the Republic and his representative in the Council of Ministers. He does not have the function of head of state, as usually happens in the parliamentary countries that have the position of prime minister. 
The European newspaper owns the column rights and sells it to other Spanish-speaking countries. Llosa broke with "El Comercio" in protest against newspaper's support to Keiko, former dictator Alberto Fujimori's daughter. Llossa, who supported Ollanta Humala in both lawsuits, accused "'El Comercio' of manipulating information and becoming "a propaganda machine for Keiko Fujimori's candidacy" (El País, 2011).

\subsection{United States}

The Odebrecht subsidiary in the United States is headquartered in the city of Coral Gables, in the state of Florida. And it is in Florida that the company maintains most of its construction projects in the country, although it still has its works in Louisiana, California, North Carolina and Texas (Odebrecht USA, s / d). The works of greater public visibility are concentrated in Miami area, such as the construction of a new airport, reforms in the main sports arena, changes in public transport and the port expansion. For that reason, the chosen newspaper in U.S. was the "Miami Herald".

In it, the news about Odebrecht can be divided into two parts. One of them concerns the scandal in other Latin American countries, such as Ecuador, Panama, Colombia and Brazil. The other is related to the construction works carried out by the company in U.S. and its clashes with state legislation, because of sanctions against companies doing business with Cuba government.

The law, proposed by Republican Party state Senators, was sanctioned by then-Gov. Rick Scott in May 2012, being effective on July 1st of that year. The rule prohibited the state government and local administrations of Florida from hiring or even accepting proposals from companies that had contracts with governments of Cuba and Syria. The company, which was then in charge of major works in the region, such as the expansion of the North terminal of Miami International Airport, was negotiating an airport expansion project with Miami-Dade County, including the construction of two hotels and spaces for rent (Whitefield, 2013). Anticipating difficulties, even before the law came into force, the company appealed to courts, in order to ensure that it would not be affected (Mazzei, 2012a). What was argued is that the rule would prevent Odebrecht from accessing contracts estimated at US \$ 1 million (Ibid., 2012). The reason was the relationship between the Brazilian company Odebrecht (parent of the US subsidiary), with the Cuba government. Using the subsidiary COI Overseas, Odebrecht was in charge of the modernization of the Cuban port of Mariel, a US \$ 800 million contract (Gutierrez, 2015).

In the lawsuit, Odebrecht claimed to be a separate company, with no direct relationship to Cuba's contracts, and that legislation tends to be unconstitutional because US states do not have the legal capacity to establish rules for international relations (Mazzei, 2012a). Days later, a federal court granted an injunction granting Odebrecht's right (Mazzei, 2012b). The state administration has resorted to appealing in this process (Mazzei, 2012c). Even so, the discussion on the subject carried on. In August 2017, the Miami Herald reported that support for Odebrecht's claims was used by Florida Senate Republican candidate Jose Felix Diaz as an argument against Democrat opponent Annette Taddeo (Mazzei, Sherman, 2017).

In the other part of the news, reports on allegations of corruption against Odebrecht in other countries contained no connection to the company's activities on American soil - an exception is an article by international affairs columnist Andrés Oppenheimer, who noted that "the company also built the Miami airport, but investigators have not disclosed any irregularities in the firm's US contracts" (Oppenheimer, 2017). An 2013 article (Whitefield, 2013) cited other major construction works of the company in Brazil (the Santo Antonio dam), in Panama (Cinta Costera), as well as projects in Colombia, Venezuela, Liberia and Portugal. At least the Santo Antonio and Cinta Costera projects are being investigated today - at the time, Lava Jato Operation in Brazil was in its infancy, and charges against Odebrecht had not yet been made. Reports on Odebrecht's Florida works and anti-Castro legislation issues were posted in the business, city (Miami-Dade) and local politics sections. Texts on corruption in places like Brazil, Panama, Colombia, Venezuela, Ecuador, Peru and the Dominican Republic have been coming out on international news.

The discrepancy between Odebrecht described in the reports on works in Florida - "Brazilian engineering and construction giant" (Mazzei, 2012b), a multinational company with 200,000 employees, presence in 25 countries, 13th largest company in its sector in the world (Whitefield, 2013) - and the corrupt company mentioned in international affairs has not gone unnoticed by Miami Herald readers. On 2016 Christmas Eve, the Floridian newspaper published a letter from Key Biscaine's reader Francisco Alzuru under the title "Probe Odebrecht":

The Brazilian group Odebrecht has been linked to corruption at Petrobras, the semi-public Brazilian multinational corporation in the petroleum industry.

Now the U.S. Department of Justice has found it guilty in the United States.

Does it surprise anyone that it has won so many contracts in Miami-Dade County?

Has the Herald or any other media investigated their activities here and how they have won so many highway construction contracts? (ibid., 2016) 
Even after the letter, there is no record of company's investigative reporting on Miami Herald website.

\subsection{Portugal}

In Portugal, the analyzed newspaper was the "Diário de Notícias", the fifth best-selling general daily newspaper in the country in the fourth quarter of 2017 (Associação Portuguesa para o Controlo de Tiragem e Circulação, 2017). The newspaper maintains systematic coverage of the Odebrecht scandal in Brazil and the involvement of the country's political world. The news also covers the company's operations in Latin America, especially Panama, Ecuador, Mexico, Colombia, Venezuela and the Dominican Republic, as well as its business in Africa, especially in Angola. In this case, the reports are located in the World editorial, sometimes coming from news agencies, especially Lusa.

A typical coverage example on Odebrecht's Latin American face of the case is the report "Odebrecht's tentacles spread throughout Latin America" (Salvador, 2017), published in February 2017. This is a survey concerning the extensions of the case in several countries of the continent, emphasizing the denunciations of high-ranking public officials' participation in the bribes paid by the company. They are nominally quoted, such as the then president of Colombia, Juan Manuel Santos; the former Colombian president Alvaro Uribe (not for direct involvement in the denunciations, but for the possible participation of a former vice-minister, not nominated); the former vice president of Guatemala Roxana Baldetti; the former president of Panama Ricardo Martinelli (for the alleged involvement of two of his sons not nominated); the former presidents of Peru Alejandro Toledo and Ollanta Humala; the former president of Peru, Pedro Pablo Kuczynski; and the president of the Dominican Republic, Danilo Medina (for his proximity to the businessman Ángel Rondón, who would have been the recipient of payments made by the contractor).

Within the Diário de Notícias website, references to countries in general are related to cooperation in investigations. In this case, they are Switzerland and Portugal. The reports continue to play an important role in Portugal, but they are not public. This is the case of the report "Lava Jato: Brazilian company wanted to stop investigation in Portugal" (Lima, 2016). In it, legal maneuvering of Odebrecht's defenders is described so that the Portuguese Justice fails to comply with a request made by the Attorney General of the Brazilian Republic, which requested bank information from persons and organizations investigated in connection with Operation Lava Jato. Another example is the report "Four 'Lava Jato' investigated bought real estate in Portugal" (Moura, 2017). According to the report, one Odebrecht executive, two of Andrade Gutierrez and one from Camargo Corrêa, all accused of authorizing the bribes' payments to public agents, had acquired properties in the country objecting to access a program that grants Portuguese citizenship to investors who buy properties with a minimum value of 500 thousand euros. According to the report (based on another story, published by the English newspaper "The Guardian"), the ultimate goal would be to escape from prison in Brazil.

There is little mention of possible Odebrecht's irregular procedures in Europe or even in Portugal. An exception to this table is a March 2018 report, which points to a poorly explained payment from Portuguese energy company EDP to construction companies Odebrecht and Lena (Portuguese). According to the newspaper, a transfer of 20 million Euros was made without technical justification, during the construction of the Baixo Sabor dam. EDP president António Mexia admitted irregular practices in the case and asked a consultancy to draw up a study to indicate why the cost of the dam jumped from 490 million euros initially forecast to 760 million euros (Dinheiro Vivo, 2018). The group, led by construction company Lena, is accused of composing, in Portugal, a criminal consortium similar to that of which Odebrecht is accused. In Operation Marquis, carried out by Portuguese authorities from the end of 2014, the group is among the business organizations accused of transferring to former Prime Minister José Sócrates values that reach 34 million euros in bribes, in exchange for advantages (Diário de Notícias, 2017).

\section{Conclusion}

In Brazil, the Odebrecht case resulted in the impeachment of Dilma Rousseff, with an important participation of the media groups, which aligned themselves with other political forces that defended the deposition (Larangeira et al., 2018). Examples of this behavior can be found, for example, in the headline "Brazil cannot stand Dilma anymore", published by the "Estado de Minas" (2016) and by the cover editorial "Nor Dilma nor Temer" (Folha de S. Paulo, 2016). Analyzing the results found in this article, different behavior patterns emerging from this can be explained by the ideological affinities of the media with segments of national elites.

In Latin America media vehicles, the conservative pattern was exposed in the way the Peru's newspaper "El Comercio" articulated a support to the group represented by Keiko Fujimori, during coverage of the crisis that resulted in the resignation of President Pedro Pablo Kuczynski. On March 7, 2018, for example, the newspaper opened headline with an interview with Fuerza Popular party's leader, saying that "President Kuczynski must resign" (El Comercio, 2018c). By attributing the citation to the candidate who faced PPK in the electoral contest, the newspaper used the subterfuge of operative neutrality, previously described, to manifest, highlighted, a favorable opinion to the government change although, in the following day, it published a president's response (El Comercio, 2018d). 
In Colombia, what happens is a kind of armistice between the newspaper "El Tiempo" and President Juan Manuel Santos - who, not by chance, is part of the family that controls the newspaper. In "El Tiempo" reports, allegations of corruption are presented, but they do not "stick" to the former president, unlike what happened in Brazil and Peru (although in Brazilian case, the Odebrecht affair was not the reason of impeachment, but one more ingredient in the negative news regarding government). In Ecuador, the divergences between the newspaper "El Universo" and the government of Rafael Correa and the pressure that he's been exerting on the communication vehicle explains the way news went from accusations against former vice-president Glas to a request of Odebrecht's apologies to the nation's citizens.

In Portugal and the United States, the scandal was treated in a different manner, presented as a foreign phenomenon, although the company involved had local businesses. The Miami Herald did not even suggest that there might be connivance between the State of Florida (or any other authority in the country) with a company considered to be corrupting in at least a dozen nations - it required a reader's intervention to have the subject addressed, even though Odebrecht has been seen in local news for other reasons.

These findings confirm what was developed in this article about the role of ideology, with local and global contexts interposing themselves in order to impose restrictions on discourses. In the cases presented here, political and informational controls exercised by and about the media define the nuances that the news reports about Odebrecht case shows, even though these controls are disguised by operative neutrality.

\section{Declaration of conflicting interests}

The author(s) declared no potential conflicts of interest with respect to the research, authorship, and/or publication of this article.

\section{References}

ASSOCIAÇÃO PORTUGUESA PARA O CONTROLO DE TIRAGEM E CIRCULAÇÃO (2017). Análise simples. http://www.apct.pt/Analise_simples.php?idSegmento=2\&ano=2017\&ordenacao=circulacao4Bi\%20DESC.

BAACK, S. (2016) What big data leaks tell us about the future of journalism - and its past. In. Internet policy review. July.https://policyreview.info/articles/news/what-big-data-leaks-tell-us-about-futurejournalism-and-itspast $/ 413$.

BOSWELL, C. (2013) Odebrecht exploring cracker, derivatives in Marcellus region. Chemical Week, 18 - 25 November, Vol.175 (29), p. 7.

BRAGIO BONALDO, R. (2017) Quando a Odebrecht construiu Salvador: a narrativa jornalística da história na coleção Terra Brasilis, de Eduardo Bueno (1998- 2006). Revista Tempo e Argumento 20(9). doi: $10.5965 / 2175180309202017130$

BRASÃO, M.P.; JÚNIOR, V.M.V. (2016) Misbehavior in Organizations: Gang at Work na empresa Odebrecht. In: Anais do Congresso Brasileiro de Estudos Organizacionais.

BRITO, V.F.; OLIVA, F.L. (2009) Razões e estratégias de internacionalização da construtora Odebrecht. FACES R. Adm. Belo Horizonte, v. 8, n. 3, p. 13-27, July/September.

doi: 10.21714/1984-6975FACES2009V8N3ART152

COLlIS, J.; HUSSEY, R. (2005) Pesquisa em administração: um guia prático para alunos de graduação e pósgraduação. Porto Alegre: Bookman.

DEPARTMENT OF JUSTICE. (2016a) United States of America against Odebrecht. https://www.justice.gov/opa/press-release/file/919911/download.

DEPARTMENT OF JUSTICE. (2016b) Odebrecht and Braskem Plead Guilty and Agree to Pay at Least \$3.5 Billion in Global Penalties to Resolve Largest Foreign Bribery Case in History.

https://www.justice.gov/opa/pr/odebrecht-and-braskem-plead-guilty-and-agree-pay-least-35-billion-globalpenalties-resolve.

DIÁRIO DE NOTÍCIAS. (2017) Operação Marquês: Quem são os 28 arguidos e do que são acusados. Diário de Notícias, 11 October. https://www.dn.pt/portugal/interior/operacao-marques-lista-dos-28-arguidos-acusados-erespetivos-crimes-8834140.html.

DINHEIRO VIVO. (2018) EDP pagou extra de 20 milhões às construtoras Lena e Odebrecht. Dinheiro Vivo, 16 march. https://www.dn.pt/dinheiro/interior/edp-pagou-extra-de-20-milhoes-as-construtoras-lena-e-odebrecht9191493.html.

EL COMERCIO. (2018a) Aprobación de PPK baja a 35\%, según encuesta de Datun. https://elcomercio.pe/politica/gobierno/aprobacion-ppk-baja-35-encuesta-datum-142562.

EL COMERCIO. (2018b) Comisión Lava Jato citará ex-presidentes a partir de agosto. 
https://elcomercio.pe/politica/comision-lava-jato-citara-ex-presidentes-partir-agosto-437505.

EL COMERCIO. (2018c) Zavala: No me aferro al cargo, mi renuncia está presentada permanentemente. https://elcomercio.pe/politica/fernando-zavala-me-aferro-cargo-mi-renuncia-presentada-permanentementenoticia-455727.

EL COMERCIO. (2018d) PPK y Keiko Fujimori se reunieron por más de dos horas en Palacio de Gobierno. https://elcomercio.pe/politica/dialogo-acompanantes-ppk-keiko-fujimori-reunen-hoy-441280.

EL COMERCIO. (2018e) PPK: allanamiento a sus propriedades duró más de 12 horas. https://elcomercio.pe/politica/ppk-allanamiento-propiedades-duro-12-horas-noticia-507082.

EL COMERCIO. (2018f) PPK: PJ dictó 18 meses de impedimento de salida del país. https://elcomercio.pe/politica/ppk-pj-dicto-18-meses-impedimento-salida-pais-noticia-506952.

EL COMERCIO. (2018g) El presidente Kuczynski debe renunciar. El Comercio, Lima, 7 march, 1.

EL COMERCIO. (2018h) "No voy a renunciar", responde PPK a pedido de Keiko. El Comercio, Lima, 8 march, 1.

EL PAÍS. (2011) Vargas Llosa rompe con el diario peruano 'El Comercio' por favorecer a Keiko Fujimori. 1 june. https://elpais.com/diario/2011/06/01/internacional/1306879210_850215.html.

EL TIEMPO. (2017a) El capítulo del escándalo Odebrecht que toca al presidente Santos. http://www.eltiempo.com/politica/gobierno/implicacion-de-santos-con-odebrecht-por-campana-de-201069168.

. (2017b) El CNE ya asignó la investigación de las campañas de Santos y Zuluaga. http://www.eltiempo.com/politica/gobierno/como-el-consejo-nacional-electoral-investigara-dineros-deodebrecht-en-campanas-57516.

(2017c) La ruta de los sobornos de Odebrecht que ya apunta a tres congresistas. http://www.eltiempo.com/justicia/investigacion/la-ruta-de-los-sobornos-de-odebrecht-en-colombia-113000. (2017d) Procuraduría abre investigación contra ocho congresistas. http://www.eltiempo.com/justicia/investigacion/investigan-a-ocho-congresistas-por-corrupcion-148960. . (2017e) Caiga quien caiga. https://www.eltiempo.com/opinion/editorial/caiga-quien-caiga-escandalo-desobornos-de-odebrecht-113392.

EL UNIVERSO. (2012) Rafael Correa anunció perdón sin olvido para sentenciados en caso EL UNIVERSO. $E l$ Universo. https://www.eluniverso.com/2012/02/27/1/1355/rafael-correa-anuncio-perdon-sin-olvidosentenciados-caso-universo.html.

. (2017a) Las claves para entender el caso de sobornos de Odebrecht en Ecuador.

https://www.eluniverso.com/noticias/2017/11/01/nota/6461932/claves-entender-caso-sobornos-odebrechtecuador.

. (2017b) Jorge Glas: Estoy en la cárcel por defender mis ideas. https://www.eluniverso.com/noticias/2017/11/15/nota/6481357/jorge-glas-estoy-carcel-defender-mis-ideas. (2018) Odebrecht pide disculpas a Ecuador por escándalo de millonarios sobornos. https://www.eluniverso.com/noticias/2018/03/06/nota/6654463/odebrecht-pide-disculpas-ecuador-escandalomillonarios-sobornos.

ESTADO DE MINAS. (2016) O Brasil que não aguenta mais Dilma. Estado de Minas, Belo Horizonte, 14 march, p. 1. FOLHA DE S. PAULO. (2016) Nem Dilma nem Temer. Folha de S. Paulo, São Paulo, 03 april, p. 1.

FLOR, G.Í. (2014) O jornalismo em tempos de WikiLeaks: uma análise do Folhaleaks e da Folha de S.Paulo. Dissertação (Mestrado em Comunicação)- Programa de Pós-graduação em Comunicação, Universidade de Brasília, Brasília.

FLYNN, K. (2011) The Practice and Politics of Leaking. Social Alternatives 30 (1): 24-28.

GONÇALVES, R. (2017) Diplomacia presidencial, corrupção, internacionalização das empreiteiras e perda de poder do Brasil no sistema internacional: o efeito bumerangue da política externa no governo Lula. Instituto de Economia. Universidade Federal do Rio de Janeiro.

GREENWALD, G. (2014) Sem lugar para se esconder. Rio de Janeiro: Sextante.

GUTIERREZ, J.A. (2015) President of Brazil's Odebrecht Corp. Detained on Charges of Corruption. Havana Times. http://www.havanatimes.org/?p=112092.

JOTA . (2018) Resultados contra Odebrecht. http://www.eltiempo.com/opinion/caricaturas/jota/resultados-contraodebrecht-109326.

KURTENBACH, S.; NOLTE, D. (2017) Latin America's Fight against Corruption: The End of Impunity. GIGA Focus Latinamerika 3.

LAKATOS, E.M.; MARCONI, M.A. (2001) Fundamentos de metodologia científica. São Paulo: Atlas. 
LAMB, I.T.; LACERDA, D.P.; DRESCH, A. (2017) A tecnologia empresarial Odebrecht como filosofia de projeto organizacional - um estudo de caso na Braskem SA. Suma de Negócios 17 (8): 31- 46. doi: 10.1016/j.sumneg.2016.08.002

LARANGEIRA, Á.N. et al. (2018) L'affaire Lula et l'action de l'imaginaire dans les grands médias brésiliens. Sociétés 139 (1): 135-146. doi: 10.3917/soc.139.0135

LEWIS, S.C. (2012) The tension between professional control and open participation. Journalism and Its Boundaries. In: Information, communication \& society: 844-851. doi: 10.1080/1369118X.2012.674150.

LIMA, C.R. (2016) Lava Jato: empresa brasileira quis travar investigação em Portugal. Diário de Notícias. https://www.dn.pt/portugal/interior/lava-jato-empresa-brasileira-quis-travar-investigacao-em-portugal5150419.html.

MACHADO, A.A.S. (2008) O caso Odebrecht e o dilema da liderança Regional Brasileira. Meridiano 47 (100): 32-36.

MALHOTRA, N.K. (2012) Pesquisa de marketing: uma orientação aplicada. Porto Alegre: Bookman.

MATTAR, F.; FOWLER, F.R.; TAVARES, M.C.; PIEREN, R.W. (1996) Redação de documentos acadêmicos: conteúdo e forma. Caderno de Pesquisas em Administração, São Paulo: FEA/USP, pp. 1-30.

MATOVSKA, M.; TRAJKOSKA, J.; SILJANOVSKA, Z. (2014) The impact of BRIKS from economic, legal and political aspect in the international community. European Scientific Journal (4), 1 February: 370(6).

MAZZEI, P. (2012a) Odebrecht sues Florida over new law banning government hiring of firms tied to Cuba. Miami Herald. http://www.miamiherald.com/latest-news/article1940369.html.

(2012b) Miami federal judge blocks new Florida anti-Cuba law from taking effect. Miami Herald. http://www.miamiherald.com/news/politics-government/article1940836.html.

(2012c) Florida won't appeal ruling against law banning public hiring of firms tied to Cuba. Miami Herald. http://www.miamiherald.com/news/local/community/miami-dade/article1954721.html.

MAZZEI, P.; SHERMAN, A. (2017) Politics, Miami-style: Senate race ad casts Democrat as Castro apologist. Miami Herald. http://www.miamiherald.com/news/politics-government/state-politics/article168078182.html.

MENA ERAZO, P. (2012) La justicia de Ecuador respalda a Correa en su batalla contra el diario "El Universo". El País. 2012. https://elpais.com/internacional/2012/02/15/actualidad/1329285187_747274.html.

MESKELL, L. (2014) States of conservation: protection, politics, and pacting within UNESCO's world heritage committee. Anthropological Quarterly 87(1): 217(27). doi: 10.1353/anq.2014.0009.

MINISTÉRIO DA FAZENDA. (2017) Fazenda divulga nota técnica sobre impactos da MP 795.http://www.fazenda.gov.br/centrais-de-conteudos/notas-tecnicas/2017/2017-11-24_notatenica_mf-rfb_mp795.pdf.

MINISTÉRIO PÚBLICO FEDERAL. (s/d.) Entenda o caso. http://www.mpf.mp.br/para-o-cidadao/caso-lavajato/entenda-o-caso

MOURA, J.A. (2017) Quatro investigados na Lava Jato compraram imóveis em Portugal. Diário de Notícias. https://www.dn.pt/mundo/interior/quatro-investigados-na-lava-jato-compraram-imoveis-em-portugal8780331.html.

ODEBRECHT ECUADOR. (2017) Comunicado | Odebrecht. [S.l: s.n.]. https://www.odebrecht.com.ec/comunicado/.

ODEBRECH USA. Projects. Available at: http://www.odebrechtusa.com/projects (accessed 20 ago. 2018).

OPPENHEIMER, A. (2017) Lessons from the Odebrecht scandal in Latin America show need for new technology. Miam Herald. http://www.miamiherald.com/news/local/news-columns-blogs/andresoppenheimer/article133176179.html.

PÊCHEUX, Michel. (2011) Análise de discurso. Campinas: Pontes Editores. . (1997) O discurso: estrutura ou acontecimento. Campinas: Pontes. . (1995) Semântica e discurso: uma crítica à afirmação do óbvio. Campinas: Editora da UNICAMP.

RIVEROS, E. (2014) Ranking: Diarios impresos más influyentes de América Latina en su versión 2.0. Huffington Post. https://www.huffingtonpost.com/eduardo-riveros/ranking-diarios-impresos-america-latina_b_4632454.html.

SALVADOR, S. (2017) Os tentáculos da Odebrecht alastram pela América Latina. 2017. Diário de Notícias. https://www.dn.pt/mundo/interior/os-tentaculos-da-odebrecht-alastram-pela-america-latina-5662984.html.

SPITZECK, H.; BOECHAT, C.; FRANÇA LEÃO, S. (2013) Sustainability as a driver for innovation-towards a model of corporate social entrepreneurship at Odebrecht in Brazil. Corporate Governance 13(5): 613-625.

VAN DIJK, T.A. (2004) Cognição, discurso e interação. São Paulo: Contexto.

VAN DIJK, T.A. (2012) Discurso e contexto. São Paulo: Contexto.

VAN DIJK, T.A. (2008) Discurso e poder. São Paulo: Contexto.

WHITEFIELD, M. (2013) Odebrecht USA - a master at winning public contracts — has run into roadblocks in its quest to build Airport City. Miami Herald. http://www.miamiherald.com/news/business/bizmonday/article1955962.html 